\title{
DESIGNING A RATIONAL AND OPTIMAL FISCAL FEDERALISM FOR NIGERIA
}

\author{
Raymond Minini ${ }^{1}$ and Selem-Amachree Ibiyingibo ${ }^{2}$ \\ School of Foundation and General Studies, Captain Elechi Amadi Polytechnic, Rumuola, \\ Port Harcourt \\ ${ }^{1}$ Email: raymondminini@yahoo.com; 07080060083 \\ ${ }^{2}$ Email: goodmother2007@yahoo.com; Tel: 08033384733
}

Cite this article:

Raymond M., Selem-

Amachree I. (2021),

Designing a Rational and

Optimal Fiscal Federalism for

Nigeria. African Journal of

Social Sciences and

Humanities Research 4(3), 56-

64. DOI: 10.52589/AJSSHR-

QHWKDQIQ.

\section{Manuscript History}

Received: 2 May 2021

Accepted: 31 May 2021

Published: 22 June 2021

Copyright $(9) 2020$ The Author(s). This is an Open Access article distributed under the terms of Creative Commons AttributionNonCommercial-NoDerivatives 4.0 International (CC BY-NC-ND 4.0 ), which permits anyone to share, use, reproduce and redistribute in any medium, provided the original author and source are credited.
ABSTRACT: Nigeria, because of its peculiar evolution-the Federal system, tends to emphasize not cooperation but competition between the constituent units and the centre, and among the constituent units themselves. Especially with the discovery of oil, bad governance and the non-performance of the public sector has re-echoed the problem of intergovernmental fiscal arrangement among the different levels of government to the front burner, which has remained dominant and most contentious in Nigeria's polity. It is upon this background, that it becomes necessary to lend a voice in designing a rational and optimal fiscal federalism for our dear nation, Nigeria, because the nature and conditions of the financial relations in any federal system are crucial to its continued existence. This paper explores revenue allocation formulas through a descriptive historical analysis, and by taking cognizance of the main issues and challenges of fiscal federalism recommended that derivation principle should be encouraged - but not relegating the national unity to the background-and corruption should be fought to a standstill without sentiment.

KEYWORDS: Federal System, Bad Governance, Public Sector, Rational, Optimal Fiscal Federalism, Nigeria 


\section{INTRODUCTION}

The concept of intergovernmental relations in most times is used in reference to the federal system of government or interactions occurring between (or among) government units of all types and levels within. This makes intergovernmental relations, otherwise known as fiscal federalism, to practically exist within the federal system alone (Chijioke et al., 2012). In other words, the term fiscal federalism itself is rooted in a political arrangement called federalism. Federalism is simply the existence of more than one level of government in one country, each with different expenditure responsibilities and taxing powers. It is a kind of non-centralization of power and authority. Fiscal federalism, according to Williams and Ogbole (2014), is all about equality and equity, justice and fair play among constituent units and between the units and the central government.

However, in Nigeria, because of its peculiar evolution, the federal system tends to emphasize not cooperation but competition between the constituent units and the centre, and among constituent units themselves (Jega, 1996) as cited by Williams and Ogbole (2014). This competition in the Nigerian context involves the Federal Government, 36 States, Federal Capital Territory (FCT), 774 Local Governments and the six development units in the Federal Capital Territory. Nigeria, as a federal state, dates back to the 1946 adoption of Richards Constitution, which granted internal autonomy to the then existing regions of Nigeria. Also, the adoption of the Lyttleton Constitution of 1954 laid further credence to the federal structure of Nigeria (Nwosu, 1980). But as a result of long years of military rule and the centralized nature of the military hierarchical structure that created the financial hegemony, enjoined by the Federal Government over the other units, and with the introduction of democratic experiment in 1999 coupled with the issue of discovery of oil and its exploitation and exploration, the politics of onshore and offshore dichotomy and the non-performance of the public sector has re-echoed the problem of intergovernmental fiscal arrangement among the different levels of government to the front burner, which has remained dominant and most contentious in Nigeria's polity.

It is upon this background it becomes necessary to lend a voice in designing a rational and optimal fiscal federalism for our dear nation-Nigeria. This will go a long way in reducing conflicts and rivalries associated with fiscal federalism and stimulating healthy fiscal independence and competition among the constituent units.

\section{CONCEPTUAL ISSUES}

\section{Federalism}

Federalism is derived from the Latin word "foedus" meaning covenant. It is a political concept in which a group of members are bound together by covenant with a governing representative head. The term is also used to describe a system of government in which sovereignty is constitutionally divided between a central governing authority and constitutional political units. Federalism is a system in which the power to govern is shared between national and state governments (Akindele \& Olaopa, 2002) as cited by Arowolo (2011). It is a political theory that is divergent in concept, varied in ecology and dynamic in practice. Sagay (2008) conceptualized federalism as an arrangement whereby powers within a multinational country are shared between a federal government and component units in such a way that each unit, 
including the central authority, exists as a government separately and independently from others, operating directly on persons and properties within its territorial area, and with a will of its own apparatus for the conduct of affairs, and with an authority in some matters exclusive of others.

The concept of federalism implies that each tier of government is coordinate and independent in its delimited sphere of authority, and should also have appropriate taxing powers to exploit its independent sources of revenue (Vincent, 2001) as cited by Ewetan et al. (2015). Wheare (1963) emphatically argued that: "if state authorities, for example, find that the services allotted them are too expensive for them to perform, and if they call upon the federal authority for grants and subsidies to assist them, they are no longer coordinate with the federal government but subordinate to it. Financial subordination brings an end to federalism, no matter how carefully the legal forms may be preserved. It follows therefore that the state and federal authorities in a federalism must each be given the power in the constitution to have access to and to control its own sufficient financial resources. Each must have power to tax and to borrow for the financing of its own services by itself".

\section{Fiscal Federalism}

Fiscal federalism is a by-product of federalism. It is in fact, a general normative framework for the assignment of functions to the different levels of government and appropriate fiscal instruments for carrying out these functions. Sharma (2005) as cited by Arowolo (2011) perceives fiscal federalism as a set of guiding principles or guiding concepts that helps in designing financial relations between the national and sub-national levels of the government; fiscal decentralization on the other hand as a process of applying such principles. According to Tella (1999), fiscal federalism refers to the financial relationship between and among existing tiers of government. It includes the system of transfers or grants by which the Federal Government shares its revenues with the States and Local Government Areas.

\section{Principles of Fiscal Federalism}

According to Agiobenebo (1999), cited by Ewetan et al., (2015), a number of principles have evolved to shape and guide intergovernmental fiscal relations practice; these include:

i. The Principle of Diversity: One justification for the adoption of the federal system is its ability to ensure unity in the midst of extreme diversities. So, the fiscal system must provide a scope for variety and differences to adequately accommodate the supply of national, regional (state) and local goods.

ii. The Principle of Equivalence: The various public goods have different geographical incidence. Therefore, allocation efficiency requires the equalization of locational advantages arising from inter-jurisdictional differences, with a combination of taxes and public goods and services.

iii. The Principle of Centralized Stabilization: This principle requires the rise of fiscal instruments for achieving macro policy objectives (stabilization, growth, etc.) at the national level.

iv. Correction of Spillover Effects: Efficiency of fiscal federalism requires that interjurisdictional externalities be corrected for by the system. Spillover effects or inter- 
jurisdictional externalities refer to externalities (both benefits enjoyed and harm suffered) by residents of different geo-political units because benefiting regions for many public goods and services are open entities. This requirement is intended to control for what in the fiscal decentralization literature is referred to as the "central city exploitation thesis", exploitation of economies of scale and the rationale for intergovernmental grant.

v. Minimum Provision of Essential Public Goods and Services: This principle requires that fiscal federalism should assure all citizens that, irrespective of where they reside, they will be provided with a minimum level of certain essential public goods and services.

vi. Fiscal Equalization Principle: Where there exists pronounced regional imbalance in resource endowment and concomitant differences in fiscal capacity of sub-national governments, there is the need for some degree of fiscal equalization among the federating units of government, to ensure minimum level of public goods and services.

vii. The Efficiency Principle: There are two dimensions in a two-step hierarchy in this principle. Firstly, it requires that, collectively, the set of criteria directing fiscal federalism should ensure efficiency in the allocation of resources in the Paretian sense. Secondly, it requires that the collective principles of intergovernmental fiscal relations should ensure that each level of government maximizes its internal revenue earnings at minimum tax efforts, with optimal distortion.

viii. The Principle of Derivation: This principle requires that the component units of a federation be able to control some of their preferences in their own way and with their own resources.

ix. The Principle of Locational Neutrality: Locational choices of both individuals and firms are influenced by interregional fiscal differences. Thus, some degree of locational interference appears to be an inevitable cost of fiscal federalism, given the natural differences in resources endowment, differences in tax capacity and effort. Policy therefore seeks to minimize the distortions arising from such interference.

x. The Principle of Centralized Redistribution: The redistribution function of fiscal policy, through progressive taxation and expenditure programmes, should be centralized at the federal level. This principle is mutually consistent with that of the principle of locational neutrality. In other words, if the redistribution function is decentralized, it can lead to distortions in local decisions.

\section{THEORETICAL ISSUES}

The Decentralization Theorem, formulated by Oats (1999), constitutes the basic foundation for what may be referred to as the first-generation theory of fiscal decentralization (Bird, 2009). The theory focused on situations where different levels of government provided efficient levels of output of public goods "for those goods whose special patterns of benefits were encompassed by the geographical scope of their jurisdictions". Such situations came to be known as "perfect mapping" or "fiscal equivalence" (Olson, 1996), as cited by Arowolo (2011). 
Nevertheless, it was also recognised that, given the multiplicity of local public goods with varying geographical patterns of consumption, there was hardly any level of government that could produce a perfect mapping for all public goods. Thus, it was recognised that there would be local public goods with interjurisdictional spillovers. For example, a road may confer public goods characteristics, the benefits of which are enjoyed beyond the local jurisdiction. The local authority may then under-provide for such a good. To avoid this, the theory then resorts to a situation whereby the central government is required to provide matching grants to the lowerlevel government, so that it can internalize the full benefits.

Based on the preceding, the role of government in maximizing social welfare through public goods provision were assigned to the lower tiers of government. The other two roles of income distribution and stabilization were, however, regarded as suitable for the central government.

From the foregoing, we can summarize the role assignment which flows from the basic theory of fiscal federalism. The central government is expected to ensure equitable distribution of income, maintain macroeconomic stability and provide public goods that are national in character. Decentralized levels of government, on the other hand, are expected to concentrate on the provision of local public goods, with the central government providing targeted grants in cases where there are jurisdiction spill-overs associated with local public goods.

The final element of this basic theory that is worthy of note is the need for fiscal equalization. This is in the form of lump sum transfers from the central government to decentralized governments. The arguments for equalization were mainly two: The first, which is on efficiency grounds, saw equalization as a way of correcting for distorted migration patterns. The second was to provide assistance to poorer regions or jurisdictions. Equalization has been important in a number of federations.

\section{REVIEW OF REVENUE COMMISSIONS AND ALLOCATION FORMULA IN NIGERIA (1946-1999)}

The issue of fiscal federalism is a unique one in Nigeria. This is because it is characterized by conflicts and rivalries, and very recently, violence in the form of agitation for resource control, especially in the Niger Delta region. The issue has, over the years, engaged the attention of various commissions and committees. They include:

i. Phillipson Commission (1946): This commission recommended the use of derivation and even development as criteria for distribution of revenue. By derivation, the commission means each unit of government would receive from the central purse the same portion it has.

ii. Hicks-Phillipson Commission (1951): This commission recommended need, derivation, independent revenue or fiscal autonomy, and national interests as the criteria for revenue sharing.

iii. Chicks Commission (1953): This commission recommended the use of derivation. 
iv. Raisman Commission (1957): It recommended need, balanced development and minimum responsibility; percentage division of $40 \%$ to the north, $31 \%$ to the east, $24 \%$ to the west and 5\% to Southern Cameroon.

v. The Binns Commission (1964): This commission rejected the principles of need and derivation. In its place, it proposed regional financial comparability and percentage division of $42 \%$ to the north, $30 \%$ to the east, $20 \%$ to the west and $8 \%$ to the midwest.

vi. Dina Commission (1969): It recommended national minimum standards, balanced development in the allocation of the states' joint account and basic needs.

vii. Aboyade Technical Committee (1977): It recommended a national minimum standard for national integration (22\%), equality of access to development opportunities (25\%), absorptive capacity (20\%), fiscal efficiency (15\%) and independent revenue effort $(18 \%)$. Other criteria are $57 \%$ to the Federal Government, $30 \%$ to State Governments, $10 \%$ to Local Governments and $3 \%$ to a special fund.

viii. Okigbo Committee (1980): It recommended percentages on principles: population $(4 \%)$, equality (4\%), social development $(15 \%)$ and internal revenue effort $(5 \%)$. Percentages for governments: Federal (53\%), States (30\%), Local Governments (10\%) and Special Fund (7\%).

ix. Danjuma Commission (1988): It recommended percentages: Federal (50\%), States (30\%), Local Governments (15\%) and Special Fund (5\%).

Other laws and decrees on revenue allocation:

- Decree 15 of 1967

- Decree 13 of 1970

- Decree 9 of 1971

- Decree 6 of 1975

- Decree 7 of 1975 (Oyeneye et al., 1988)

x. $\quad$ Revenue Mobilisation Allocation and Fiscal Commission (1999):

The establishment in 1999 of Revenue Mobilisation Allocation and Fiscal Commission (RMAFC) was a response by the Federal Government to provide for an all-embracing and permanent revenue body in Nigeria. RMAFC is a body that reflects the Federal Character Principle in its membership composition and has enabling laws which empower the commission to act as follows:

1) Monitor the accruals into and disbursement of revenue from the federation account;

2) Review from time to time, the revenue allocation formula and principles in operation, to ensure conformity with changing realities; 
3) Advise the Federal, State and Local governments on fiscal efficiency and methods by which their revenue is to be increased;

4) Determine the remuneration appropriate to political office holders; and

5) Discharge such other functions as may be conferred on the commission, through the constitution or any act of the National Assembly (Shuaibu, 2002).

\section{ISSUES AND CHALLENGES OF FISCAL FEDERALISM IN NIGERIA}

The major challenge of fiscal federalism is to ensure equitable distribution of resources to all groups that make the country, Nigeria, and at the same time, guarantee that the geese that lay the golden eggs are adequately rewarded. But there are several issues that are tormenting its achievement. They are

\section{Assignment of revenue from natural resources}

Nigeria is a nation endowed with viable mineral resources in virtually all the states. (Chijioke et al., 2012 citing Tell, 2005), but petroleum has been the only major natural resource that is prominent in fiscal revenue.

\section{Corruption}

Public sector corruption is an economic woe that has bedeviled the Nigerian economy. And it is dependent on the nature of accountability relations between the government and citizens, among others. The inability of the citizens to understand what has been happening to their shares drives them to agitate for another revenue formula.

\section{Regional Disparities and National Unity}

Nigeria contains within its boundaries a significant territorially-based group of people who are, or who consider themselves to be, distinct and different in ethnicity, language, religion or just in history from the majority of the population. This results in antagonistic conflicts and rivalries among them.

\section{CONCLUSION AND RECOMMENDATION}

Having gone through the review of issues of fiscal federalism and intergovernmental relations practice in Nigeria, a rational and optimal revenue sharing formula should be as follows:

\section{i. Vertical Allocation Formula}

Federal Government 40\%, States 30\%, Local Governments 20\%, Special Fund $10 \%$. 


\section{ii. Horizontal Allocation Formula}

\begin{tabular}{|c|c|c|c|c|}
\hline Equality & $45.23 \%$ & Terrain & & $5.35 \%$ \\
\hline Population & $20.6 \%$ & Rural road/Inland way & - & $1.21 \%$ \\
\hline Population density & $-1.45 \%$ & Portable water & - & $1.5 \%$ \\
\hline Internal revenue effor & $\mathrm{t}-13.31 \%$ & Education & - & $3 \%$ \\
\hline Land mass & $-5.35 \%$ & Health & - & $3 \%$ \\
\hline
\end{tabular}

The rationales behind the recommended revenue allocation formula are not far fetched:

1. The federal share of $40 \%$, which is the highest, is to ensure that the nation remains one and an indivisible state. It is the federal that maintains the Armed Forces and the Police that will defend the country against external aggression. According to Yakubu Gowon, Goodluck Jonathan, Olusegun Obasanjo and General Mohammadu Buhari, the President of the Federal Republic of Nigeria, "To keep Nigeria one is a task that must be done". "Nigerian nation is non-negotiable". "No room for agitators". It is in line with the above that the highest share is given to the Federal Government, for finance is strength.

2. In the horizontal revenue allocation formula, $13 \%$ is given to derivation because of the ecological disasters that have befallen these areas whose livelihood, especially agriculture and fishing, have been wiped out by pollution resulting from oil exploitation. This is in line with the opinion of Ofuebe (2005), that states from which the bulk of the revenue is derived should be entitled to get an extra share, beyond what every other state receives.

\section{RECOMMENDATION}

The problem of economic development in Nigeria is not a result of the various sharing formulas. It is simply politicized. The intractable problems arising from the widely unacceptable and constant conflicting fiscal federalism are the handwork of corrupt government officials. It is a subtle way of diverting the attention of the good people of Nigeria. In recent years, concerns about corruption have mounted in tandem with growing evidence of its detrimental impact on growth and development (World Bank, 2004). It is therefore strongly recommended that fighting corruption to a standstill is the only way one can examine the actual differences in results of the different revenue allocation formulas suggested so far, and the geese that lay the golden eggs should be carried along.

\section{REFERENCE}

Agiobenebo, T.J. (1999). Assignment, Criteria and the Fiscal Constitution: An Excursion into a Theory of Rational Fiscal Federalism. Proceedings of the Annual Conference of the Nigerian Economic Societ, 25-51

Arowolo, D. (2011). Fiscal Federalism in Nigeria: Theory and Dimensions. Afro Asian Journal of Social Sciences Vol. 2 No. 22 Quarter 112011. 
Chijioke, S.U., Okechukwu, E. and Jeffry, E. (2012). Issues in Nigerian Fiscal Federalism: The Relationship between the principle of Derivation and Resource Control. Kuwait Chapter of Arabian Journal of Business and Management Review. Vol.1 No. 5 January, 2012.

Ewetan,O.O., Ike, D.N. and Ige, C.S. (2015). An Examination of /Relevant Issues in Nigeria's Fiscal Federalism. International Journal of Research in Humanities and Social Studies Vol.2, Issue 3, March, 2015.

Sagay, I. (2008). “How a True Federal System Should Run”. The Nation. Lagos. Vintage Press Limited, May $19^{\text {th }} 2008$.

Tella, S.A. (1999). Promoting States Economic Independence through Financial Market Cooperation In Fiscal Federalism and Nigeria's Economic Development. Proceedings of the Annual Conference of the Nigeria Economic Society, 171-187.

Williams, E.A. and Ogbole, F.E. (2014). Fiscal Federalism in Nigeria: An Analysis of Issues and Challenges. International Journal of Peace and Conflict Studies. Vol.2 No. 1 March 2014. 